\title{
A reassessment of Anthurium species with palmately divided leaves, and a reinterpretation of Anthurium section Dactylophyllium (Araceae)
}

\author{
Thomas B. Croat' ${ }^{1}$, Mónica M. Carlsen ${ }^{1,2}$ \\ I Missouri Botanical Garden, P.O. Box 299, St. Louis, MO 63166, USA 2 Department of Biology, University \\ of Missouri-St. Louis, One University Boulevard, St. Louis, MO 63121, USA \\ Corresponding author: Mónica M. Carlsen (monica.carlsen@mobot.org)
}

Academic editor: W. John Kress | Received 23 January 2013 | Accepted 12 May 2013 | Published 10 June 2013

Citation: Croat TB, Carlsen MM (2013) A reassessment of Anthurium species with palmately divided leaves, and a reinterpretation of Anthurium section Dactylophyllium (Araceae). PhytoKeys 23: 41-54. doi: 10.3897/phytokeys.23.4754

\begin{abstract}
A reappraisal is made of the Anthurium Schott species with palmately divided leaves with 3 or more segments free to the base (i.e. palmatisect leaves), previously recognized as section Dactylophyllium Schott (Engler), as well as those species with 5 or more segments united at the base (i.e. palmatifid leaves), formerly placed in section Schizoplacium Schott (Engler). New molecular data indicates that several species (A. pedatum (Kunth) Schott, A. pedatoradiatum Schott, and possibly, A. podophyllum (Schltdl. \& Cham.) Kunth) should be excluded from section Schizoplacium, and other species previously placed in that section cannot be separated from section Dactylophyllium. Thus, Anthurium section Schizoplacium is here synonymized within section Dactylophyllium and type species are designated for both groups. This paper also provides an updated description of section Dactylophyllium as here emended, listing the 24 accepted taxa now included (20 species and 4 varieties or subspecies), along with their geographic distributions.
\end{abstract}

\section{Keywords}

Anthurium, molecular phylogeny, palmately divided leaves, palmatisect leaves, palmatifid leaves, section Schizoplacium, sectional classification

Copyright Thomas B. Croat, Mónica M. Carlsen. This is an open access article distributed under the terms of the Creative Commons Attribution License 3.0 (CC-BY), which permits unrestricted use, distribution, and reproduction in any medium, provided the original author and source are credited. 


\section{Introduction}

Anthurium Schott species with palmately divided leaves (as included in Madison 1978) represent a very distinct morphological group within the genus (Fig. 1). In these species, leaf segments (i.e. leaflets) are free to the base, in palmatisect leaves, or leaf segments (i.e. lobes) are united at the base, in palmatifid leaves (Fig. 2). The current sectional classification of Anthurium (Croat and Sheffer 1983) separates these species into two groups, section Dactylophyllium (Schott) Engler (Engler 1879), comprising species with three or more segments (leaflets) free to the base (Fig. 2 A-B), and section Schizoplacium (Schott) Engler (Engler 1879), including species with five or more segments (lobes) united at the base (Fig. 2 C). A recent molecular phylogeny (Carlsen 2011, Carlsen and Croat in press) has shown that most of the species of Anthurium with palmately divided leaves belong to a single highly supported clade (Fig. 3, Clade 3), therefore suggesting that previous divisions of the group are unnecessary. Indeed, the newly circumscribed Clade 3 merits sectional rank. Moreover, although all members of Clade 3 share palmately divided leaves, this leaf form has evolved independently at least two more times within Anthurium, in Clades 14 and 16 (Fig. 3). The goal of this study is to reevaluate the limits of sections Dactylophyllium and Schizoplacium in the light of the new molecular evidence and provide an updated description of this redefined group of Anthurium species with palmately divided leaves (Fig. 1).

\section{Taxonomic history}

In the first comprehensive revision of the genus, Schott (1860) classified Anthurium species with lobed or divided leaves in three groups (Table 1): grex Semaeophyllium, comprising species with "hastate-trilobed" blades with segments united at the base; grex Schizoplacium, including species with "pedately-partite" blades with five or more leaf segments united at the base (i.e. palmatifid leaves, according to our definition) (Fig. 2 C); and grex Dactylophyllium, containing species with "digitisect" leaf blades with three or more segments divided completely (i.e. free) to the base (i.e. palmatisect leaves, in our definition) (Fig. $2 \mathrm{~A}-\mathrm{B}$ ).

Carlsen and Croat (2007) recently revised the 23 species included in Anthurium section Semaeophyllium (Schott) Engler (Engler 1879). The section comprises species with trilobed leaf blades, where leaf lobes are always united at the base, and the lobes can be directed forward (i.e. falcate) or to the sides (i.e. spreading) but never toward the back. On the basis of molecular evidence (Carlsen 2011, Carlsen and Croat in press), section Semaeophyllium appears not to be monophyletic. However, species with trilobed leaves are more closely related to other Anthurium species with cordate leaves than to the species with palmately divided leaf morphology clustered in Clade 3 (Carlsen 2011, Carlsen and Croat in press). Therefore, this paper will only deal with the Anthurium species with palmately divided leaves (Fig. 1), those included in sections Dactylophyllium and Schizoplacium. 


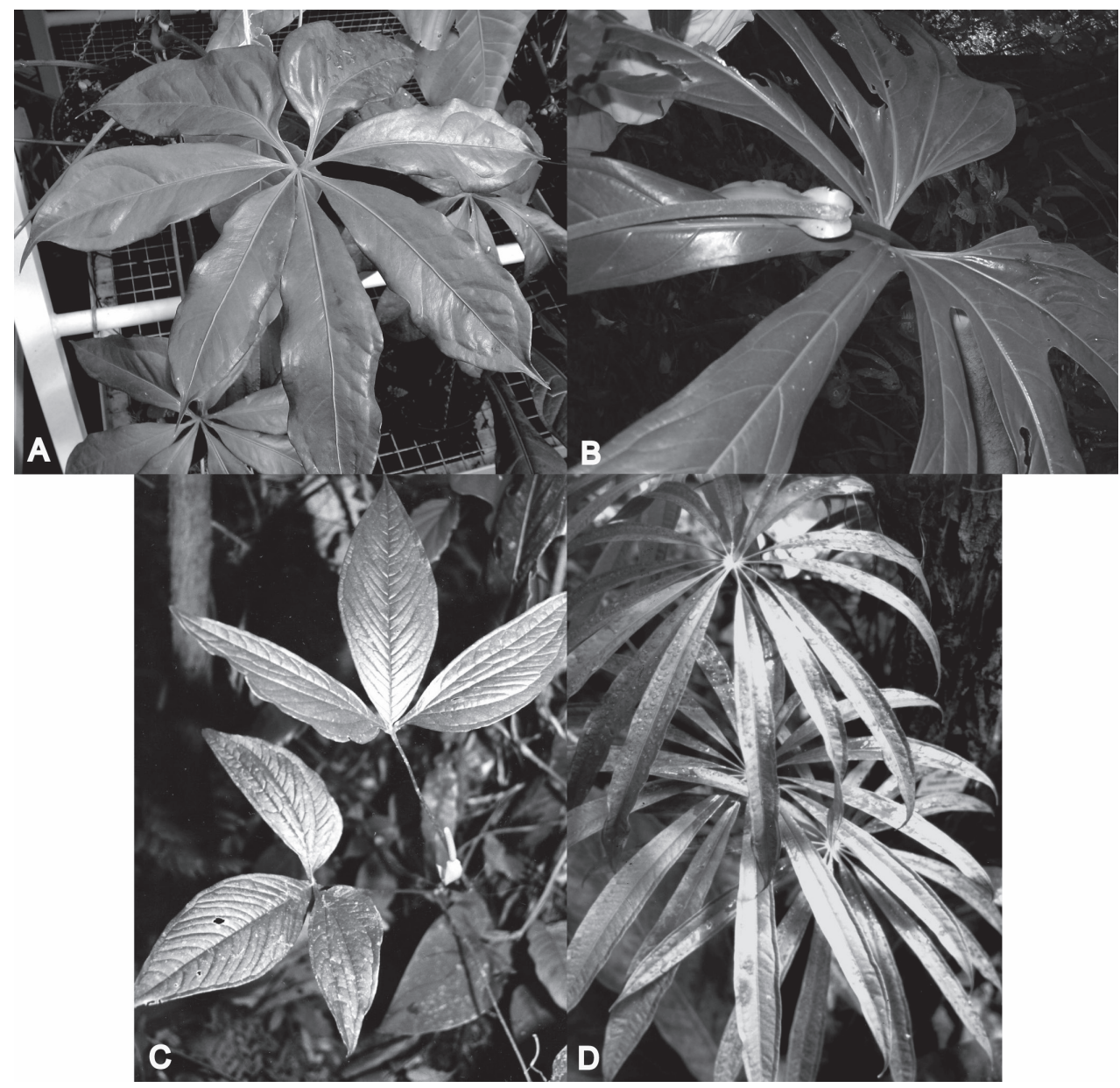

Figure I. Examples of Anthurium species with palmately divided leaves here included in section Dactylophyllium (Schott) Engler emend. Croat \& Carlsen. A Palmatisect leaf with seven leaflets of Anthurium pentaphyllum (Aubl.) G.Don var. pentaphyllum (M. Leppard 1395) B Palmatifid leaf of Anthurium longissimum Pittier ssp. longissimum (M. Carlsen 2126) C Palmatisect leaves with three leaflets of Anthurium trisectum Sodiro (T.B. Croat 48977) D Palmatisect leaves with more than 9 leaflets of Anthurium polydactylum Madison (T.C. Plowman \& H. Kennedy 5769).

Schott (1860) included 27 names in his grex \# 28 (Table 1), Dactylophyllium, but according to the most updated species synonymy for the genus (Govaerts et al. 2012), only seven species are currently recognized: Anthurium clavigerum Poepp., A. digitatum (Jacq.) Schott, A. eminens Schott, A. kunthii Poepp., A. pentaphyllum (Aubl.) G.Don, A. sinuatum Benth, and A. triphyllum (Willd. ex Schult.) Brongn. ex Schott. On the other hand, Schott (1860) included seven names in his grex \# 27 (Table 1), Schizoplacium, but only four species are now recognized, A. palmatum (L.) Schott, A. pedatoradiatum Schott, A. pedatum (Kunth) Schott, and $A$. podophyllum (Schltdl. \& Cham.) Kunth. Engler (1879) gave formal sectional ranking 


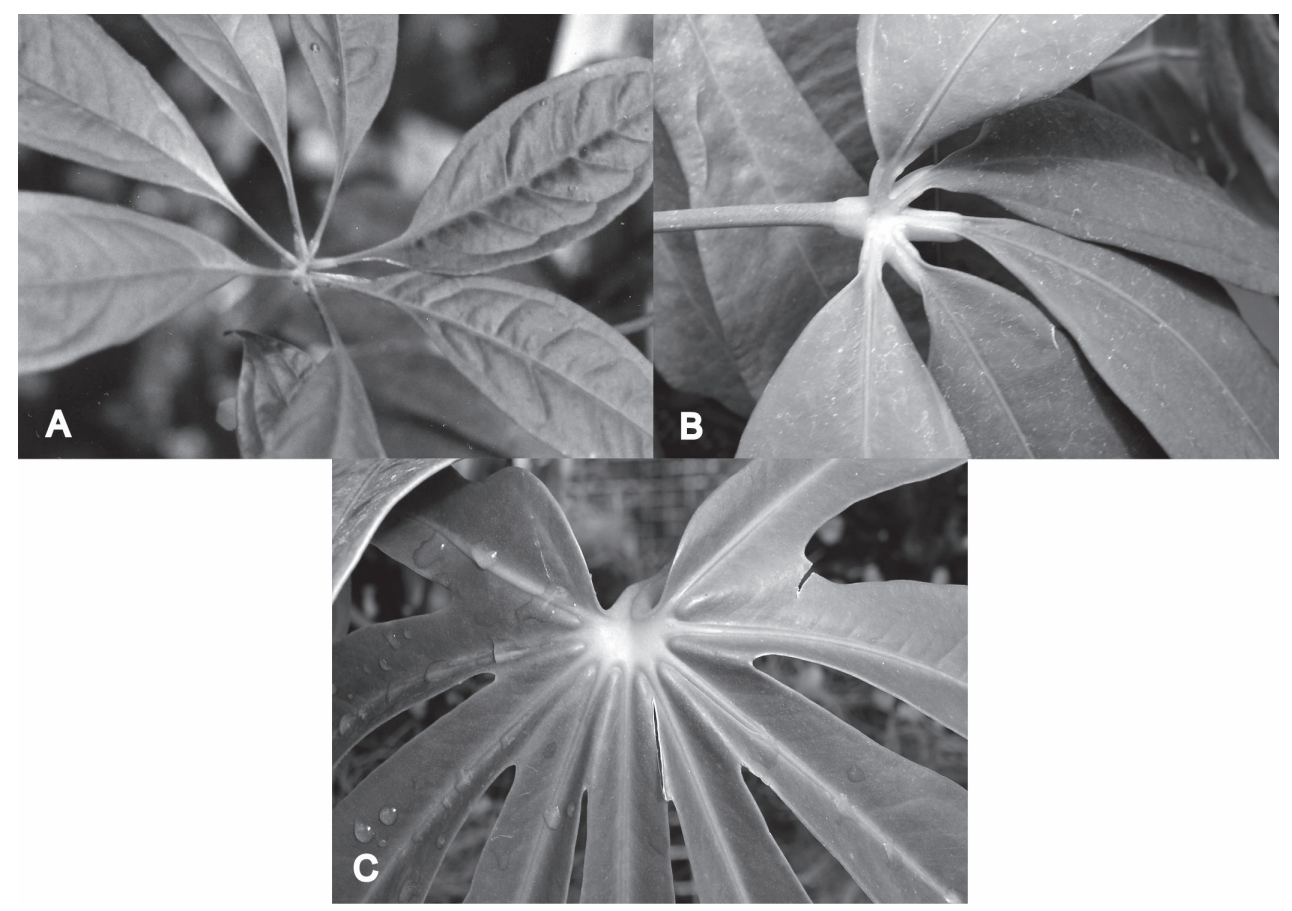

Figure 2. Detail of leaf bases of Anthurium species with palmately divided leaves. A Palmatisect leaf with segments (leaflets) free to the base with long petiolules, Anthurium kunthii Poepp. var. kunthii (J.P. Folsom 3228) B Palmatisect leaf with segments (leaflets) free to the base with short petiolules, Anthurium pentaphyllum (Aubl.) G.Don var. pentaphyllum (R.M. Harley 18334) C Palmatifid leaf with segments (lobes) united at the base, Anthurium palmatum (L.) Schott (Kew living collection 1980-554).

to these, and others, of Schott's greges, maintaining the species circumscriptions in both groups.

However, Engler (1905) made major modifications in the classification of Schott. He described his newly circumscribed section Semaeophyllium as comprising species with "hastate-trilobed or pedatisect or digitisect" leaf blades, and very long and relatively thin (i.e. myosuroideous) spadices. Engler (1905) included in his new version of section Semaeophyllium, along with more typical species with trilobed leaves, a pair of species from Schott's grex Dactylophyllium (namely A. sinuatum and A. clavigerum) and also A. palmatum, previously placed by Schott in grex Schizoplacium. Alternatively, Engler's amended section Schizoplacium (Engler 1905) included the remaining species of both Schott's greges Dactylophyllium and Schizoplacium, along with a few more recently described species, for a total of 17 species, of which only eight are currently accepted (Table 1). Engler's (1905) new delimitation of section Schizoplacium included species with "pedately-partite" leaf blades, with segments either united at the base or completely separated, and thick, conic spadices. He further divided this section into two informal groups, $\$ 1$. Euschizoplacium Engler, with short stems and internodes, but long peduncles, and $\$ 2$. Dactylophyllium (Schott) Engler, with scandent stems, elon- 
Table I. Anthurium species with palmately divided leaves formerly included in Dactylophyllium and Schizoplacium, a comparison of previous circumscriptions. This is not an exhaustive list of all species names that have been previously included in these groups, it only contains taxa that were accepted at the time of publication of each work. Names in bold denote species included in the newly redefined section Dactylophyllium (Schott) Engler emend. Croat \& Carlsen, as proposed here. Species marked with $\left(^{*}\right)$ are now formally excluded from this emended section. All other species names are either synonyms or species dubia, fide Madison (1978).

\begin{tabular}{|c|c|c|c|c|c|}
\hline Species name & $\begin{array}{c}\text { Year } \\
\text { published }\end{array}$ & Schott $(1860)$ & Engler (1905) & Madison (1978) & $\begin{array}{c}\text { Croat \& Sheffer } \\
\text { (1983) }\end{array}$ \\
\hline A. aemulum Schott & 1859 & Dactylophyllium & $\begin{array}{c}\text { Schizoplacium series } \\
\text { Dactylophyllium }\end{array}$ & $\begin{array}{c}\text { synonym of } \\
\text { A. pentaphyllum } \\
\text { var. bombacifolium }\end{array}$ & \\
\hline A. andersonii Schott & 1857 & Dactylophyllium & $\begin{array}{c}\text { Schizoplacium series } \\
\text { Dactylophyllium }\end{array}$ & $\begin{array}{l}\text { synonym of } \\
\text { A. palmatum }\end{array}$ & \\
\hline $\begin{array}{c}\left(^{*}\right) \text { A. angustisectum } \\
\text { Engl. }\end{array}$ & 1898 & & & Group 6 & Schizoplacium \\
\hline $\begin{array}{l}\text { A. araliaefolium } \\
\text { Regel }\end{array}$ & 1869 & & $\begin{array}{c}\text { Schizoplacium series } \\
\text { Euschizoplacium }\end{array}$ & $\begin{array}{l}\text { species dubium, } \\
\text { probably a hybrid }\end{array}$ & \\
\hline $\begin{array}{l}\text { A. arisaemoides } \\
\text { Madison }\end{array}$ & 1978 & & & $\begin{array}{c}\text { Group } 7 \\
\text { Schizoplacium }\end{array}$ & Dactylophyllium \\
\hline A. aubletii Kunth & 1841 & Dactylophyllium & $\begin{array}{c}\text { synonym of } \\
\text { A. pentaphyllum }\end{array}$ & $\begin{array}{c}\text { synonym of } \\
\text { A. pentaphyllum } \\
\text { var. pentaphyllum }\end{array}$ & \\
\hline $\begin{array}{l}\text { A. bombacifolium } \\
\text { Schott }\end{array}$ & 1858 & Dactylophyllium & $\begin{array}{l}\text { synonym of } \\
\text { A. aemulum }\end{array}$ & $\begin{array}{c}\text { A. pentaphyllum } \\
\text { var. bombacifolium }\end{array}$ & \\
\hline $\begin{array}{c}A . \\
\text { brevipedunculatum } \\
\text { Madison }\end{array}$ & 1978 & & & $\begin{array}{c}\text { Group } 7 \\
\text { Schizoplacium }\end{array}$ & Dactylophyllium \\
\hline $\begin{array}{c}\text { A. buchtienii } \mathrm{K} . \\
\text { Krause }\end{array}$ & 1910 & & & $\begin{array}{c}\text { Group } 7 \\
\text { Schizoplacium } \\
\end{array}$ & Dactylophyllium \\
\hline $\begin{array}{c}\text { A. clavigerum } \\
\text { Poepp. }\end{array}$ & 1845 & Dactylophyllium & Semaeophyllium & $\begin{array}{c}\text { Group } 7 \\
\text { Schizoplacium }\end{array}$ & Dactylophyllium \\
\hline $\begin{array}{l}\text { A. clavigerum var. } \\
\text { subpedatipartitum } \\
\text { Engl. }\end{array}$ & 1905 & & Semaeophyllium & not mentioned & \\
\hline A. croatii Madison & 1978 & & & $\begin{array}{c}\text { Group } 7 \\
\text { Schizoplacium }\end{array}$ & Dactylophyllium \\
\hline $\begin{array}{c}\text { A. digitatum (Jacq) } \\
\text { Schott }\end{array}$ & 1829 & Dactylophyllium & $\begin{array}{l}\text { Schizoplacium series } \\
\text { Dactylophyllium }\end{array}$ & $\begin{array}{l}\text { A. pentaphyllum } \\
\text { var. digitatum } \\
\text { Group } 7 \\
\text { Schizoplacium }\end{array}$ & not mentioned \\
\hline A. elegans Engl. & 1881 & & $\begin{array}{c}\text { Schizoplacium series } \\
\text { Euschizoplacium }\end{array}$ & $\begin{array}{l}\text { synonym of } \\
\text { A. palmatum }\end{array}$ & \\
\hline A. eminens Schott & 1855 & Dactylophyllium & $\begin{array}{c}\text { Schizoplacium series } \\
\text { Dactylophyllium }\end{array}$ & $\begin{array}{c}\text { Group } 7 \\
\text { Schizoplacium }\end{array}$ & Dactylophyllium \\
\hline $\begin{array}{c}\text { A. expansum } \\
\text { Gleason }\end{array}$ & 1929 & & & Group 6 & Schizoplacium \\
\hline A. fissum K. Koch & 1864 & & Semaeophyllium & $\begin{array}{l}\text { synonym of } \\
\text { A. palmatum }\end{array}$ & \\
\hline $\begin{array}{l}\text { A. ghiesbrechtii } \\
\text { Linden ex Schott }\end{array}$ & 1860 & Schizoplacium & $\begin{array}{c}\text { synonym of } \\
\text { A. podophyllum }\end{array}$ & not mentioned & \\
\hline A. grossum $\mathrm{Schott}$ & 1859 & Dactylophyllium & $\begin{array}{c}\text { A. pentaphyllum var. } \\
\text { grossum }\end{array}$ & $\begin{array}{c}\text { synonym of } \\
\text { A. pentaphyllum } \\
\text { var. pentaphyllum }\end{array}$ & \\
\hline $\begin{array}{l}\text { A. helleborifolium } \\
\text { Schott }\end{array}$ & 1862 & & $\begin{array}{c}\text { Schizoplacium series } \\
\text { Euschizoplacium }\end{array}$ & $\begin{array}{c}\text { synonym of } \\
\text { A. pedatoradiatum }\end{array}$ & \\
\hline
\end{tabular}




\begin{tabular}{|c|c|c|c|c|c|}
\hline Species name & \begin{tabular}{|c|} 
Year \\
published
\end{tabular} & Schott $(1860)$ & Engler (1905) & Madison (1978) & $\begin{array}{c}\text { Croat \& Sheffer } \\
(1983)\end{array}$ \\
\hline $\begin{array}{l}\text { A. hoffmannseggii } \\
\text { Schott }\end{array}$ & 1857 & Dactylophyllium & $\begin{array}{c}\text { synonym of } \\
\text { A. pentaphyllum }\end{array}$ & $\begin{array}{l}\text { synonym of } \\
\text { A. kunthii }\end{array}$ & \\
\hline $\begin{array}{l}\text { A. holtonianum } \\
\text { Schott }\end{array}$ & 1857 & Dactylophyllium & Semaeophyllium & $\begin{array}{l}\text { synonym of } \\
\text { A. clavigerum }\end{array}$ & \\
\hline $\begin{array}{l}\text { A. holtonianum var. } \\
\text { cohaerens Engl. }\end{array}$ & 1905 & & Semaeophyllium & not mentioned & \\
\hline A. kalbreyeri Mast. & 1881 & & $\begin{array}{c}\text { Schizoplacium series } \\
\text { Dactylophyllium }\end{array}$ & $\begin{array}{l}\text { synonym of } \\
\text { A. clavigerum }\end{array}$ & \\
\hline A. karwinskii Schott & 1859 & Dactylophyllium & $\begin{array}{l}\text { synonym of } \\
\text { A. aemulum }\end{array}$ & $\begin{array}{c}\text { synonym of } \\
\text { A. pentaphyllum } \\
\text { var. bombacifolium }\end{array}$ & \\
\hline A. kunthii Poepp. & 1845 & Dactylophyllium & $\begin{array}{c}\text { Schizoplacium series } \\
\text { Dactylophyllium }\end{array}$ & $\begin{array}{c}\text { Group } 7 \\
\text { Schizoplacium } \\
\end{array}$ & Dactylophyllium \\
\hline $\begin{array}{c}\text { A. longissimum } \\
\text { Pittier }\end{array}$ & 1947 & & & Group 6 & Schizoplacium \\
\hline A. martini Schott & 1857 & Dactylophyllium & Semaeophyllium & $\begin{array}{l}\text { synonym of } \\
\text { A. sinuatum }\end{array}$ & \\
\hline $\begin{array}{l}\text { A. ottonianum } \\
\text { Kunth }\end{array}$ & 1841 & Dactylophyllium & $\begin{array}{l}\text { A. variabile var. } \\
\text { ottonianum }\end{array}$ & not mentioned & \\
\hline $\begin{array}{l}\text { A. pachirifolium } \\
\text { Schott }\end{array}$ & 1855 & Dactylophyllium & $\begin{array}{c}\text { Schizoplacium series } \\
\text { Dactylophyllium }\end{array}$ & $\begin{array}{l}\text { synonym of } \\
\text { A. pentaphyllum } \\
\text { var. pentaphyllum }\end{array}$ & \\
\hline $\begin{array}{l}\text { A. pachirifolium var. } \\
\text { angustifolium Engl. }\end{array}$ & 1881 & & $\begin{array}{c}\text { Schizoplacium series } \\
\text { Dactylophyllium }\end{array}$ & $\begin{array}{c}\text { synonym of } \\
\text { A. pentaphyllum } \\
\text { var. pentaphyllum }\end{array}$ & \\
\hline $\begin{array}{l}\text { A. palmatum (L.) } \\
\text { Schott }\end{array}$ & 1829 & Schizoplacium & Semaeophyllium & Group 6 & Schizoplacium \\
\hline $\begin{array}{l}\text { A. panduratum } \\
\text { Mart. ex Schott }\end{array}$ & 1855 & Dactylophyllium & Semaeophyllium & $\begin{array}{l}\text { synonym of } \\
\text { A. clavigerum }\end{array}$ & \\
\hline $\begin{array}{l}\text { A. panduratum var. } \\
\text { burchellianum Engl. }\end{array}$ & 1905 & & Semaeophyllium & $\begin{array}{l}\text { synonym of } \\
\text { A. clavigerum }\end{array}$ & \\
\hline $\begin{array}{c}\left(^{*}\right) A . \text { pedatoradiatum } \\
\text { Schott }\end{array}$ & 1859 & Schizoplacium & $\begin{array}{c}\text { Schizoplacium series } \\
\text { Euschizoplacium }\end{array}$ & Group 4 & Schizoplacium \\
\hline $\begin{array}{l}\left(^{*}\right) \text { A. pedatum } \\
\text { (Kunth) Schott }\end{array}$ & 1829 & Schizoplacium & $\begin{array}{c}\text { Schizoplacium series } \\
\text { Euschizoplacium }\end{array}$ & Group 5 & Schizoplacium \\
\hline $\begin{array}{l}\text { A. pentaphyllum } \\
\text { (Aubl.) G. Don }\end{array}$ & 1839 & Dactylophyllium & $\begin{array}{c}\text { Schizoplacium series } \\
\text { Dactylophyllium }\end{array}$ & $\begin{array}{c}\text { Group } 7 \\
\text { Schizoplacium }\end{array}$ & Dactylophyllium \\
\hline $\begin{array}{l}\text { A. pentaphyllum } \\
\text { var. bombacifolium } \\
\text { (Schott) Madison }\end{array}$ & 1978 & & & $\begin{array}{c}\text { Group } 7 \\
\text { Schizoplacium }\end{array}$ & Dactylophyllium \\
\hline $\begin{array}{c}\left(^{*}\right) \text { A. podophyllum } \\
\text { (Schltdl. \& Cham.) } \\
\text { Kunth }\end{array}$ & 1841 & Schizoplacium & $\begin{array}{l}\text { Schizoplacium series } \\
\text { Euschizoplacium }\end{array}$ & Group 4 & Schizoplacium \\
\hline $\begin{array}{c}\text { A. polydactylum } \\
\text { Madison }\end{array}$ & 1978 & & & $\begin{array}{c}\text { Group } 7 \\
\text { Schizoplacium }\end{array}$ & Dactylophyllium \\
\hline $\begin{array}{l}\text { A. polyschistum } \\
\text { R.E. Schultes \& } \\
\text { Idrobo }\end{array}$ & 1959 & & & $\begin{array}{c}\text { Group } 7 \\
\text { Schizoplacium }\end{array}$ & Dactylophyllium \\
\hline A. polytomum Schott & 1859 & Schizoplacium & $\begin{array}{c}\text { synonym of } \\
\text { A. podophyllum }\end{array}$ & $\begin{array}{c}\text { synonym of } \\
\text { A. podophyllum }\end{array}$ & \\
\hline $\begin{array}{c}\text { A. pseudopodophyllum } \\
\text { Schott }\end{array}$ & 1859 & Schizoplacium & $\begin{array}{c}\text { synonym of } \\
\text { A. podophyllum }\end{array}$ & $\begin{array}{c}\text { synonym of } \\
\text { A. podophyllum }\end{array}$ & \\
\hline A. repandum Schott & 1857 & Dactylophyllium & Semaeophyllium & $\begin{array}{l}\text { synonym of } \\
\text { A. clavigerum }\end{array}$ & \\
\hline $\begin{array}{c}\text { A. sinuatum Benth } \\
\text { ex Schott }\end{array}$ & 1857 & Dactylophyllium & Semaeophyllium & $\begin{array}{c}\text { Group } 7 \\
\text { Schizoplacium }\end{array}$ & not mentioned \\
\hline
\end{tabular}




\begin{tabular}{|c|c|c|c|c|c|}
\hline Species name & $\begin{array}{c}\text { Year } \\
\text { published }\end{array}$ & Schott $(1860)$ & Engler (1905) & Madison (1978) & $\begin{array}{c}\text { Croat \& Sheffer } \\
(1983)\end{array}$ \\
\hline $\begin{array}{l}\text { A. smilaciforme K. } \\
\text { Koch }\end{array}$ & 1855 & Dactylophyllium & $\begin{array}{l}\text { synonym of } \\
\text { A. undatum }\end{array}$ & not mentioned & \\
\hline $\begin{array}{l}\text { A. sonderianum } \\
\text { Schott }\end{array}$ & 1858 & Dactylophyllium & $\begin{array}{l}\text { synonym of } \\
\text { A. pentaphyllum }\end{array}$ & $\begin{array}{c}\text { synonym of } \\
\text { A. pentaphyllum } \\
\text { var. pentaphyllum }\end{array}$ & \\
\hline A. sylvestre S. Moore & 1895 & & Semaeophyllium & $\begin{array}{l}\text { synonym of } \\
\text { A. sinuatum }\end{array}$ & \\
\hline A. thrinax Madison & 1978 & & & $\begin{array}{c}\text { Group } 7 \\
\text { Schizoplacium } \\
\end{array}$ & Dactylophyllium \\
\hline $\begin{array}{c}\text { A. triphyllum } \\
\text { (Willd. ex Schult.) } \\
\text { Brongn. ex Schott }\end{array}$ & 1860 & Dactylophyllium & $\begin{array}{c}\text { Schizoplacium series } \\
\text { Dactylophyllium }\end{array}$ & $\begin{array}{c}\text { Group } 7 \\
\text { Schizoplacium }\end{array}$ & Dactylophyllium \\
\hline A. trisectum Sodiro & 1905 & & & $\begin{array}{c}\text { Group } 7 \\
\text { Schizoplacium }\end{array}$ & Dactylophyllium \\
\hline A. undatum Schott & 1832 & Dactylophyllium & $\begin{array}{c}\text { Schizoplacium series } \\
\text { Dactylophyllium }\end{array}$ & $\begin{array}{c}\text { synonym of } \\
\text { A. pentaphyllum } \\
\text { var. pentaphyllum }\end{array}$ & \\
\hline $\begin{array}{c}\text { A. undatum var. } \\
\text { undulifolium (K. } \\
\text { Koch ex Ender) Engl. }\end{array}$ & 1878 & & $\begin{array}{c}\text { Schizoplacium series } \\
\text { Dactylophyllium }\end{array}$ & not mentioned & \\
\hline $\begin{array}{c}\text { A. undulatum K. } \\
\text { Koch \& C. D. } \\
\text { Bouché }\end{array}$ & 1854 & Dactylophyllium & $\begin{array}{l}\text { synonym of } \\
\text { A. undatum var. } \\
\text { undulifolium }\end{array}$ & not mentioned & \\
\hline A. variabile Kunth & 1841 & Dactylophyllium & $\begin{array}{c}\text { Schizoplacium series } \\
\text { Dactylophyllium }\end{array}$ & $\begin{array}{c}\text { synonym of } \\
\text { A. pentaphyllum } \\
\text { var. pentaphyllum }\end{array}$ & \\
\hline $\begin{array}{l}\text { A. warscewiczii K. } \\
\text { Koch }\end{array}$ & 1855 & Dactylophyllium & $\begin{array}{l}\text { synonym of } \\
\text { A. sinuatum }\end{array}$ & not mentioned & \\
\hline A. wendlandii Schott & 1858 & Dactylophyllium & Semaeophyllium & $\begin{array}{l}\text { synonym of } \\
\text { A. clavigerum }\end{array}$ & \\
\hline
\end{tabular}

gated internodes, but peduncles often short (Engler 1905). Engler placed most of the species from Schott's grex Schizoplacium in the Euschizoplacium group and the remaining species from Schott's grex Dactylophyllium in the Dactylophyllium group (Table 1).

The last taxonomic revision of Anthurium species with palmately divided leaves (Madison 1978) recognized 27 species and three varieties divided into seven "natural" groupings based on the author's understanding of the taxonomy, morphology and growth habit of the species (Table 1). Groups 1-3 included species with trilobed leaves with falcate lobes united at the base now placed in section Semaeophyllium (Carlsen and Croat 2007). The remaining groups in Madison's (1978) revision included typical examples of species in sections Dactylophyllium and Schizoplacium (Table 1; following Croat and Sheffer 1983). Group 4 contained two terrestrial Mexican species with short stems, elongated peduncles and "pedately divided" (i.e. palmatifid) leaf blades (A. pedatoradiatum and A. podophyllum). Group 5 consisted only of the Colombian species $A$. pedatum, with deeply dissected leaf blades with 11-15 lobes, and a pendent inflorescence borne on an erect peduncle. Group 6 included climbers with palmately divided leaves with the lobes united at the base (i.e. palmatifid leaves) (Fig. 2 C), and elongated spadices, which range from northern Colombia to the West Indies ( $A$. an- 
gustisectum Engl., A. expansum Gleason, A. longissimum Pittier and A. palmatum). The species in Madison's groups 4, 5 and 6 were placed in section Schizoplacium by Croat and Sheffer (1983). His group 7 is a predominantly Amazonian group of species with "digitisect" (i.e. palmatisect) leaf blades, where the leaf segments are free to the base and have a basal pulvinus (Fig. 2 A-B), and spadices are purple to gray. Madison called this group section Schizoplacium, apparently following Engler's (1905) circumscription of that section, but it indeed includes species placed in section Dactylophyllium by both Schott (1860) and Croat and Sheffer (1983) (Table 1).

Croat and Sheffer (1983) provided the previously accepted treatment of the sections of Anthurium with palmately divided leaf blades. Following Schott's (1860) original classification system, they separated the species of Anthurium with lobed or divided leaf blades into three sections, Semaeophyllium, Schizoplacium and Dactylophyllium (Table 1). They provided a key to the sections, descriptions, and illustrative examples of species belonging to each group.

\section{Results and discussion}

The current molecular phylogeny of the genus Anthurium, based on chloroplast (trn $G$ intron, $\operatorname{trn} H-p s b A$ and $\operatorname{trn} C-y c f 6$ intergenic spacers) and nuclear (first intron of $C H S$ and partial flanking coding regions) DNA sequences (Carlsen 2011, Carlsen and Croat in press) shows that the palmately divided leaf morphology is homoplasious within the genus, having evolved at least three times independently, in Clades 3, 14 and 16 (Fig. 3).

Based on this molecular phylogeny (Carlsen 2011, Carlsen and Croat in press) (Fig. 3), some of the Anthurium species with palmately divided leaves previously recognized as section Schizoplacium (Schott 1860, Engler 1879, Engler 1905, Croat and Sheffer 1983), do not form a monophyletic group and are not even closely related to other palmately divided species. For example, $A$. pedatum, a high elevation Colombian species with a highly divided palmatifid leaf blade, consistently clustered in the moderately supported Clade 14 (Fig. 3), along with $A$. furcatum Sodiro, with trilobed leaves, and $A$. tremulum Sodiro and $A$. macleanii Schott, both with cordate leaves. Clade 14 is not easily characterized morphologically, although most of its species have hooded spathes and pendent spadices (Carlsen and Croat in press). Madison (1978) had pointed out the possible segregation of $A$. pedatum from all other palmately divided Anthurium species by placing it alone in Group 5 of his revised classification. Molecular data now suggests that indeed $A$. pedatum is not closely related to other palmately divided Anthurium species and therefore does not belong to section Dactylophyllium as currently defined here.

Anthurium pedatoradiatum, a Mexican species with palmatifid leaves and a member of section Schizoplacium (fide Schott 1860, Engler 1879, Engler 1905, Croat and Sheffer 1983), should also be removed from this group. Results of molecular analyses (Carlsen 2011, Carlsen and Croat in press) strongly suggest that it is more closely related to other northern Central American species (Clade 16) than to the clade of 


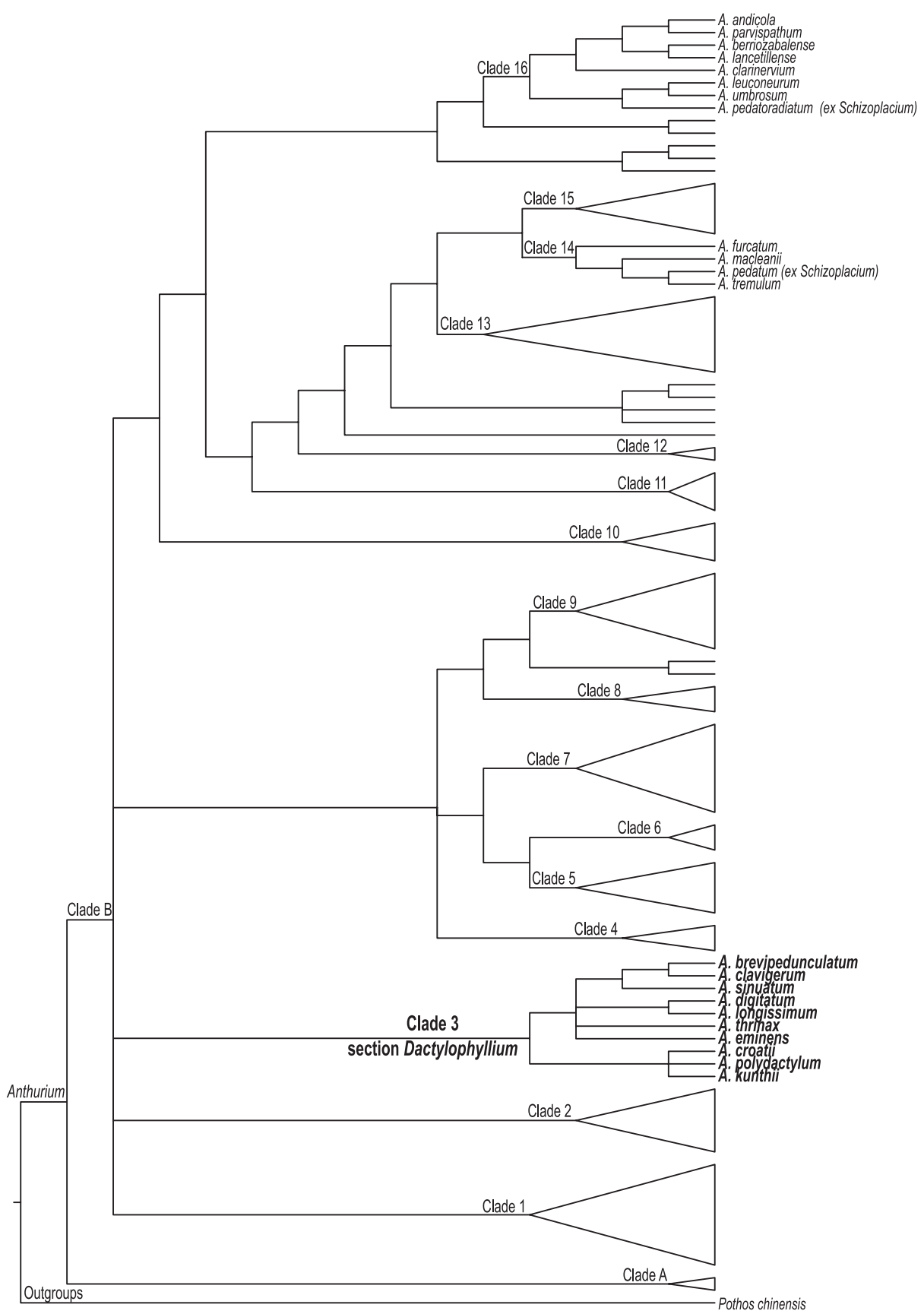

Figure 3. A schematic molecular phylogeny of Anthurium showing major clades recovered by Carlsen and Croat (in press). This phylogeny was based on combined chloroplast ( $\operatorname{trn} G$ intron, $\operatorname{trn} H-p s b A$ and $\operatorname{trn} C-y c f 6$ intergenic spacers) and nuclear (first intron of $C H S$ and partial flanking coding regions) DNA sequences. Clade numbering follow these authors. Species in bold are recognized here as members of Anthurium section Dactylophyllium (Schott) Engler, emend. Croat \& Carlsen. Placement of Anthurium species now excluded from grex Schizoplacium Schott is also shown. 
Anthurium species with palmately divided leaves (Clade 3) (Fig. 3). The strongly supported Clade 16, although quite variable in terms of leaf morphology, presents very uniform reproductive features, including only species that possess bright orange berries with a mealy mesocarp, characteristics also found in $A$. pedatoradiatum. Madison (1978) previously separated $A$. pedatoradiatum from the rest of palmately divided $A n$ thurium species, and grouped it along with the other Mexican species with palmatifid leaves, $A$. podophyllum, in his Group 4. The latter species have not been sampled for the current molecular phylogeny of Anthurium (Carlsen 2011, Carlsen and Croat in press). However, geographical affinities and similarities in fruit characteristics with other species of Clade 16 (Fig. 3) have made us consider that A. podophyllum is also a member of this clade, and as such, it should be excluded from section Dactylophyllium as delimited here.

There are only four currently recognized species names included in the original description of Schott's grex Schizoplacium (Schott 1860), all of which match well the protologue of the section. However, according to molecular studies (Carlsen 2011, Carlsen and Croat in press) (Fig. 3), A. pedatum, A. pedatoradiatum, and very likely A. podophyllum, do not belong to the same clade and are not closely related to other palmately divided Anthurium species. Therefore, these three species are also excluded from section Dactylophyllium according to the circumscription presented here. Thus, of the initial group, only $A$. palmatum remains. This climbing plant with elongated internodes and palmatifid leaves (Fig. 2 C), restricted to the Lesser Antilles, is therefore here selected as the lectotype species for section Schizoplacium. Two other Anthurium species with palmatifid leaves (A. expansum and A. longissimum) (Fig. $1 \mathrm{~B}$ ) also belong to this section under its traditional circumscription (Table 1). Anthurium palmatum was not sampled in the current molecular phylogeny of the genus (Carlsen 2011, Carlsen and Croat in press) (Fig. 3), but the closely related A. longissimum, with which it shares climbing habit, palmatifid leaf morphology, peduncle shorter than the petiole, green spathe, grayish purple spadix and reddish-purple berries, was used as a representative of this group of palmatifid species.

The molecular phylogeny of Anthurium (Carlsen 2011, Carlsen and Croat in press) clearly shows that most of the palmately divided species sampled in the study (except for A. pedatum and A. pedatoradiatum), belong in a single clade, Clade 3 (Fig. 3). These species were previously included in either section Schizoplacium (e.g. A. longissimum, a representative of the group with palmatifid leaves) or section Dactylophyllium by Croat and Sheffer (1983). The findings of molecular analyses indicate that the group of species with palmatifid leaf morphology (i.e. A. longissimum, A. palmatum and A. expansum) (Figs $1 \mathrm{~B}, 2 \mathrm{C}$ ), all sharing similar vegetative and reproductive characters, is not distinct from other species with palmately divided leaves. Thus, these two sections are here combined, and the morphological limits of this emended, more inclusive, group are redefined.

In terms of nomenclatural choice, since both names, Schizoplacium and Dactylophyllium, were published, albeit without a formal rank (i.e. as grex names), at the same time in Schott's (1860) revision of the genus Anthurium, and were later simul- 
taneously formalized as sections by Engler (1879), none of them has priority over the other. Therefore, in this study, section Schizoplacium, the smaller (probably containing only three currently accepted species names) and geographically more isolated group (mainly occurring in the Lesser Antilles and Cordillera de la Costa in Venezuela) has been placed into synonymy with the larger (probably including a total of 21 species, some undescribed) and more widespread group, section Dactylophyllium.

Anthurium kunthii (Fig. 2 A) is here chosen as the lectotype for this emended section Dactylophyllium for several reasons. Anthurium kunthii was among the original species included in Schott's (1860) first delimitation of the group and represents very well the morphological characters described in the protologue. Also, this species was sampled in the current molecular phylogeny of the genus (Carlsen 2011, Carlsen and Croat in press) (Fig. 3), and it clearly belongs to the group of species with palmately divided leaves in Clade 3. Additionally, A. kunthii is among the oldest species described within the group (in 1845) (Table 1), but unlike $A$. digitatum (the oldest described species, from 1829), its taxonomic status as a species has not been previously questioned.

The following section provides an updated description of Anthurium section Dactylophyllium (Schott) Engler, emend. Croat \& Carlsen, and lists all currently recognized species now comprising this group and their known geographic distribution.

\section{Taxonomic treatment}

Anthurium section Dactylophyllium (Schott) Engler, emend. Croat \& Carlsen, Prodr. Syst. Aroid. 542. 1860. Lectotype (designated here): Anthurium kunthii Poepp., Nov. Gen. Sp. Pl. 3: 84-85. 1845.

Figures 1, 2

Anthurium grex Schizoplacium Schott, Prodr. Syst. Aroid. 538. 1860. Lectotype (designated here): Anthurium palmatum (L.) Schott, Wiener Z. Kunst 1829(3): 828. 1829.

Remarks. Mostly appressed-climbing or scandent plants with internodes usually longer than broad, or terrestrial short stemmed plants; roots moderately sparse at each node on climbing plants, sometimes moderately dense on terrestrial species with short internodes; cataphylls usually persisting as fibers, sometimes deciduous, rarely persisting intact, the cataphyll fibers typically pale, sometimes dark reddish brown; petioles typically subterete, usually at least weakly sulcate adaxially, typically drying greenish to gray-green, sometimes dark brown; blades palmately divided and deeply lobed with 5-7 lobes united at the base (i.e. palmatifid leaves) (Figs 1 B, 2 C) (Anthurium expansum, $A$. longissimum, and $A$. palmatum) or palmatisect with segments (leaflets) divided completely to base and free (Fig. 2 A-B), sometimes 3-sect (Fig. $1 \mathrm{C}$ ) (A. arisaemoides Madison, $A$. thrinax Madison, $A$. triphyllum, and $A$. trisectum Sodiro), more commonly 5-11-sect (Fig. 1 A, D) (A. brevipedunculatum Madison, A. clavigerum, $A$. 
croatii Madison, A. eminens, A. kunthii, A. pentaphyllum, A. polyschistum R.E. Schultes \& Idrobo, and $A$. sinuatum), the petiolules of each segment short or long (Fig. 2 A-B), the segments usually entire, sometimes sinuate (A. clavigerum, A. sinuatum) or weakly to strongly pinnately lobed (A. clavigerum); the medial segment or lobe largest; side segments or lobes diminishing in size; juvenile blades simple; leaf surface usually smooth, glabrous, generally drying greenish, sometimes yellow-brown or dark brown; midrib typically raised on both surfaces; primary lateral veins typically conspicuous, usually well spaced, weakly raised or sunken above, usually narrowly rounded and prominently raised below; tertiary veins typically visible, sometimes moderately wellraised beneath. INFLORESCENCE short- (A. brevipedunculatum, A. pentaphyllum) or more commonly long-pedunculate; spathe typically green, spreading, sometimes ovate and erect (A. brevipedunculatum), usually persistent; spadix green to purplish violet, usually long-tapered, sometimes short-tapered. FRUITS purple, violet-purple or reddish-purple berries.

Species of Anthurium included in section Dactylophyllium, under this revised delimitation, are mainly distributed in the Amazon lowlands, with a few widespread species ranging into Central America (A. clavigerum, A. kunthii, and A. trisectum), and into the Atlantic coast of South America to Brazil (A. pentaphyllum). Three taxa have disjunct distributions in the coastal mountain ranges of the Cordillera Central of Venezuela (A. digitatum and A. longissimum) and the Lesser Antilles (A. palmatum).

Presently, 24 accepted taxa (20 species and 4 varieties or subspecies) occur in section Dactylophyllium as emended here. These taxa and their geographic distribution are as follow:

Anthurium arisaemoides Madison (Ecuador, Peru)

A. brevipedunculatum Madison (Bolivia, Brazil, Colombia, Ecuador, Peru)

A. buchtienii K.Krause (Bolivia)

A. clavigerum Poepp. (widespread, Nicaragua to Venezuela and Peru)

A. croatii Madison (Bolivia, Brazil, Colombia, Ecuador, Peru)

A. digitatum (Jacq.) Schott (Venezuela)

A. eminens Schott var. eminens (Bolivia, Brazil, Colombia, Ecuador, French Guiana)

A. eminens Schott var. longispadix Croat \& M.Mora (Colombia)

A. expansum Gleason (French Guiana, Guyana, Suriname, Venezuela)

A. kunthii var. cylindricum Croat (Bolivia)

A. kunthii Poepp. var. kunthii (Costa Rica to Peru and Bolivia) (Fig. 2 A)

A. longissimum Pittier ssp. longissimum (Venezuela) (Fig. 1 B)

A. longissimum Pittier ssp. nirguense Bunting (Venezuela)

A. moonenii Croat \& E.G.Gonçalves (French Guiana)

A. palmatum (L.) Schott (Lesser Antilles) (Fig. 2 C)

A. pentaphyllum (Aubl.) G. Don var. bombacifolium (Schott) Madison (Belize, Costa Rica, Guatemala)

A. pentaphyllum (Aubl.) G.Don var. pentaphyllum (widespread Costa Rica to the Guianas, Brazil and Peru) (Figs 1 A, 2 B) 
A. polydactylum Madison (Bolivia, Peru) (Fig. 1 D)

A. polyschistum R.E. Schultes \& Idrobo (Brazil, Colombia, Ecuador, Peru)

A. sinuatum Benth ex Schott (Brazil, French Guiana, Suriname, Venezuela)

A. thrinax Madison (French Guiana, Guyana)

A. triphyllum (Willd. ex Schult.) Brongn. ex Schott (Bolivia, Ecuador, Peru)

A. trisectum Sodiro (Costa Rica to Ecuador) (Fig. 1 C)

A. zuloagae Croat (Colombia)

There are also at least four more currently undescribed species in the section, and at least two more varieties that need formal recognition. A complete taxonomic revision, including identification keys, species synonymy, descriptions and illustrative photographs, of all the species of Anthurium with palmately divided leaves comprising the newly amended section Dactylophyllium is indeed needed, but beyond the scope of this article.

\section{Acknowledgements}

This study was based, in part, on the results of the PhD dissertation of the second author, and thus MMC would like to thank Peter Stevens (Advisor), Elizabeth Kellogg, Mick Richardson and Simon Mayo for helpful discussions. This study was supported by a National Science Foundation Doctoral Dissertation Improvement Grant (DEB0709851), and graduate research grants from the Botanical Society of America, the American Society of Plant Taxonomists, the Garden Club of America, the Desmond Lee Fund at the University of Missouri-St. Louis, and the Royal Botanical Gardens in Kew, England with a Kew Latin American Research Fellowship. MMC is also thankful to the W. R. Harris World Ecology Center at the University of Missouri-St. Louis through its Christensen Fellowship, and the Missouri Botanical Garden for financial support during her doctoral studies. We would also like to thank two anonymous reviewers for their valuable suggestions to improve the original manuscript.

\section{References}

Carlsen MM (2011) Understanding the origin and rapid diversification of the genus Anthurium Schott (Araceae), integrating molecular phylogenetics, morphology and fossils. $\mathrm{PhD}$ thesis, University of Missouri-St. Louis, USA. https://apps.umsl.edu/webapps/weboffice/ ETD/query.cfm?id=r6587

Carlsen MM, Croat TB (2007) Taxonomic revision of Anthurium section Semaeophyllium Schott (Araceae). Harvard Papers in Botany 12(1): 173-234. doi: 10.3100/1043-4534(2007)12[173:TROASS]2.0.CO;2

Carlsen MM, Croat TB (in press) A molecular phylogeny of the species-rich Neotropical genus Anthurium (Araceae) based on combined chloroplast and nuclear DNA. Systematic Botany. 
Croat TB, Sheffer RS (1983) The sectional groupings of Anthurium (Araceae). Aroideana 6(3): 85-123.

Engler A (1879) Araceae. In: De Candolle A, De Candolle C (Eds) Monographiae Phanerogamarum Prodomi vol. II. C. Wolf \& Fils, Munich, 1-681.

Engler A (1905) Araceae-Pothoideae. In: Engler A (Ed) Das Pflanzenreich IV 23B (Heft 21). W. Engelmann, Leipzig and Berlin, 1-330.

Govaerts R, Bogner J, Boos J, Boyce PC, Cosgriff B, Croat TB, Gonçalves E, Grayum MH, Hay A, Hetterscheid WLA, Ittenbach S, Landolt E, Mayo SJ, Murata J, Nguyen VD, Sakuragui CM, Singh Y, Thompson S, Zhu G (2012) World Checklist of Araceae. http:// www.kew.org/wcsp/ [accessed 24.06.2012]

Madison MT (1978) The species of the Anthurium with palmately divided leaves. Selbyana 2: 239-282.

Schott HW (1860) Prodromus Systematis Aroidearum. Typis Congregationis Mechitharisticae, Vienna, 1-602. 